\title{
The Inter-Relationship of Cognitive and Affective Trust Towards Servant Leadership
}

\author{
Syaiful Bakhtiar Bin Zulkifli ${ }^{1}$, Mohd Shazwan Syafiq Bin Ishak ${ }^{2}$, Mohd Subri Tahir ${ }^{3}$, \\ Samsudin Wahab ${ }^{4}$, Adi Izhar Che Ani ${ }^{5}$ \\ \{syaiful.bakhtiar@gmail.com ${ }^{1}$, shazwansyafiq.ishak@gmail.com² ${ }^{2}$, mohdsubri@uitm.edu.my ${ }^{3}$, \\ samsudinw@uitm.edu.my ${ }^{4}$, adiizhar@uitm.edu.my ${ }^{5}$ \} \\ Universiti Teknologi MARA Cawangan Pulau Pinang, Malaysia ${ }^{1}$, Universiti Teknologi MARA \\ Cawangan Pulau Pinang, Malaysia ${ }^{2}$, Universiti Teknologi MARA Cawangan Pulau Pinang, Malaysia ${ }^{3}$, \\ Universiti Teknologi MARA Cawangan Pulau Pinang, Malaysia ${ }^{4}$, Universiti Teknologi MARA \\ Cawangan Pulau Pinang, Malaysia ${ }^{5}$
}

\begin{abstract}
As such, a study on leadership in public healthcare organizations corcening servant leadership among nurses to be an essential variables that influences job performance. As there is a severe lack of studies on the relationship between the role of cognitive and affective trust with servant leadership in public heathcare. There is a growing number of nurses in public healthcare of Malaysia. With the increasing of the numbers we believe strong leadership skill is important in high job performance. Previous studies show that combination of cognitive and affective based trust plays a crucial role contributing to the servant leadership performance. Few studies have been done in determining the relationship of cognitive and affective based trust towards the leader performance. This paper theoretically aims to assess the influence of cognitive and affective trust towards servant leadership.
\end{abstract}

Keywords: Cognitive, Affective, Trust, Communication, Servant Performance.

\section{Introduction}

In the public service organizations like Ministry of Health (MOH) played an important role in the public health sector and been responsible agency for one of the large organizations workforce in the Malaysia public service. Of these, nurses make up a significant number of the much necessary workforce in the Malaysian public health service. The reality is the nurses do more than playing second fiddle to the doctor. Nurses corresponds to the physical and mental act of providing attention to those who are ill. As one of the front liners in the healthcare field, nurses are responsible for a multi tasks, such as prescribing medication, wound care and recovery, conducting physical exams and diagnostic tests, monitoring vital signs and supporting patient recovery. While the role of doctors is not ignored, it is nurses who provide the sick with holistic care, monitor allergies and medication reactions, provide continuous treatment and provide the doctor with vital information. Literally, nurses seem to be embracing a pragmatic approach, displaying dedication, thriving in the face of challenges and dedicating themselves to their duties. These qualities, which are committed to work, are likely to lead to higher job performance and contribute to greater overall organizational success. Thus, in ensuring that the objectives and outputs of the organization are met, it can be seen in a nutshell that nurses also have the quality of leadership by instilling cotrust based among them in term of leadership performance. 
Leaders who express more than self-related concern about others often show signs of humbleness. This situation encourages close ties with followers, making it easier for followers to embrace their goals and objectives related to their work [1] [2]. At once, servant leadership was first initiated in 1970, but until lately it attracts the interest of academic researchers. Study on servant leadership is under way at an accelerated tempo today. There are psychometrically sound measures available, and servant leadership has passed the test of displaying incremental validity after accounting for the two most commonly discussed approaches to leadership, leader-member exchange, and transformational leadership. Now that servant leadership has gained credibility in the academic field, development in theory is expected to direct their further development [3]. Therefore, this study is necessary to see nurses' performance as servant leaders serving in the organization as well as assessing their leadership qualities.

A servant leader shares power, puts others' needs first, helps individuals improve and maximize performance, is eager to learn from others, and forsakes personal advancement and rewards. Servant leaders concentrate on performance management, day-to-day coaching, and helping people accomplish it. They offer vision and their team understands their goals and their expected outcome. The servant's ultimate responsibility is indeed the enduring investment in the lives of those who follow the leader [4] [5]. Previous studies have been shown that leadership plays a crucial role in influencing the ultimate organizational outcome, and in particular output [1]. However, few efforts were made to understand the influence of servant leadership on how employees evaluate their performance and whether the role of cognitive and affective trust among employees is shaped by such a relationship. According to[6], there is not enough research has been done to ratify the outcomes predicted by the theory of servant leadership. Therefore, this study is conduct to able to understand the performance of servant leadership, cognitive and affective based trust among nurses in the context of the public health sector in Malaysia.

\section{Methods}

This paper represents the literatures on cognitive trust effect of followers creativity. This basis article is on the earlier stage of proposal before conducting a real field research to prove the hypothesis. Therefore, this article is discussing the reviewed of available literature about trust element either cognitive or affective that might affect creativity of clinical staff employees.

Our study will insight the influence of trust towards leaders performance. We need to emphasis in the methodology about the construct of trust by focusing at individual-level performance. The conceptual searh is aim to improve our understanding the new area of study, focusing on unravelling servant leadership convoncing on individual-level acheivement. Our aim was to explore how servant leadership effects performance in an individual performing workplace environment, proposing the influencing role of trust construct. In this study, we use the model below for explaining the relationship between cognitive and affective trust towards servant leadership effect on individual performance among nurses. 


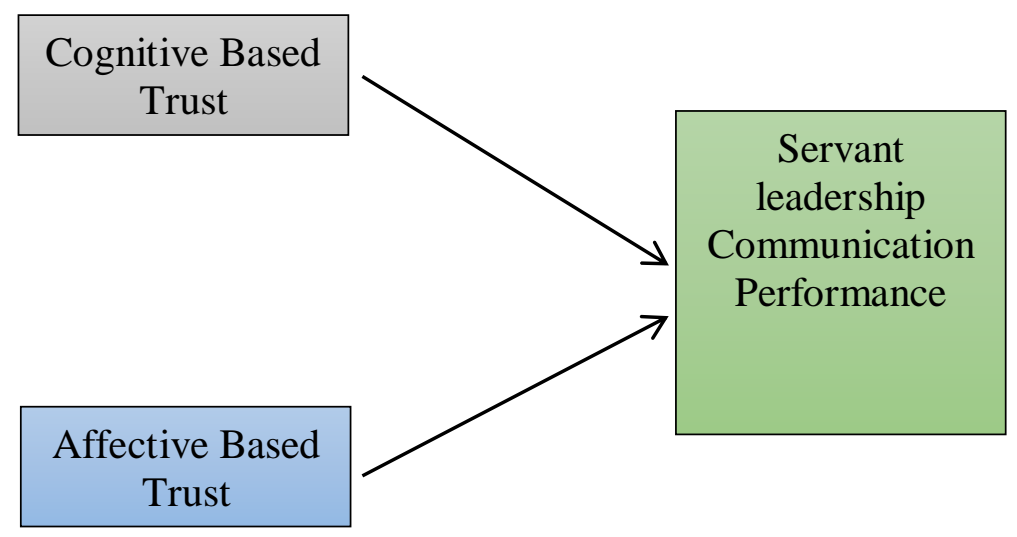

Figure 1. Theoretical Framework showing the association of bi-dimensional trust on Servant Leadership Performance

\section{Result and Discussion}

\subsection{Servant Leadership Performance}

Evidence from studies throughout the past decades on the effects of servant leadership is attributable to [6] for pioneering work paving the way for the study of the servant leadership form [7]. Since then numerous approaches have been explored for understanding the impact of servant leadership on organizations. Servant leadership is founded on the idea that leaders who are less associated with achieving personal objectives and more motivated to achieve followers are more likely to inspire those around them [8]. Effective servant leadership among nurses in public healthcare in Malaysia is critical to deliver reliable performance while meeting organizational challenges. Nurses encounter particular challenges relating to regulation and accreditation, inefficiencies in the process, patient difficulties, resource allocation, job satisfaction and patient satisfaction. The main objective of servant leadership is to serve and meet the needs of the follower [9]. Servant leadership representing leaders philosophy covering the concerns of ethics [10]. A servant leader prioritizes dedication to the organization's members rather than personal accomplishment, and focuses on meeting the needs of its members [8]. Servant leadership thus focuses on the dual focus of achieving organizational objectives as well as the growth and development of its staff, centered on the emotional cohesion between the leader and the organization's members [11], and it can play a significant role in supporting the overall satisfaction of the members of the organization's work. It is a demanding research area on servant leadership linking the ethical, virtues and morality element of leaders $[12,13]$. The special attention is on the leaders role as a servant that foster the positive organizational outcome. [14] [15] [16]. Given the problems associated with public healthcare, such as the shortage of nurses, it is incredibly important to manage rising allocation and to have an increased demand for better clinical care and productivity improvements that include healthcare staff, especially nurses. Despite these issues and because the nursing career is demanding, the involvement of nurses in the workforce in public healthcare in Malaysia is strategically important. 


\subsection{Contribute to Leader Performance \\ 3.2.1 Cognitive Based Trust}

The confidence of followers in the capacities of the leader is seen as the primary element of cognition based trust. Cognitive trust depends on the follower's personal appraisal of the leader i.e. whether or not the leader has shown competence, reliability and integrity in the past.

Knowledge and business competence are two important factors which make followers trust a leader and their leadership belonging. Cognitive trust is primarily how sure somebody feels about the technical capacity of the leader to do the job. It is based on the Leader's subjective evaluation by each individual, through certain qualities such as qualifications and award received might increase level of the cognitive trust in a group. From [17] [18], mentioned that cognition-based trust involves logic, which is based on evidence supporting the other person's reliability and competence under specific circumstances. Previous research has found that trust as a bi-dimensional variable whereas cognitive trust as the tool for competent and responsibility instead of affective trust representing emotional feeling on faith and interaction [19]. Recent development of leadership study incorporated this two dimension as valid for trust measurement.. We broaden [19] line of thought and analyse the effect of perceived trustworthiness in the servant leadership performance relation. In analysing the relationship between servant leadership performance and cognitive and affect based trust, previous research by [20] showed that cognitive trust is the key to increasing the benefits of cognitive conflict while affect-based trust is the miracle cure for cognitive conflictive. In other words, both cognitive and affect based trust have a different role and plays crucial role in managing conflict between colleague. This will indirectly have impacted the leadership performance as well. Moreover, [21] indicate that affective trust and cognitive trust mediate between the transformation leadership and organizational commitment positively. Affective trust and cognitive trust both mediate negatively between transformational leadership and task performance. Numbers of research held resulted with a different outcome. Since the aim of this study is to investigate the process on how cognitive and affective trust influences and interacts with servant leadership performance, as well their downlink staff as person player in the organization, as an informer that reflex leadership performance, we concentrated on the trust of the subordinates in their leadership. To further investigate the relationship, we would include nurses in public service organizations such as Ministry of Health $(\mathrm{MOH})$ as our study population. Nurses make up a significant number of the much necessary workforce in the Malaysian public health service. The reality is the nurses do more than playing second fiddle to the doctor. As one of the front liners in the healthcare field, nurses are responsible for a multi tasks, such as prescribing medication, wound care and recovery, conducting physical exams and diagnostic tests, monitoring vital signs and supporting patient recovery. Meaning that, nurses are the closest example for implementation and evaluation of servant leadership performance.

\subsubsection{Affective Based Trust}

In servant leadership, the interaction process (explicit or implicit) towards their followers is key for communication [22] [23]. Thus, leader-follower relationships are considered to be a dynamic phenomenon which can be affected by many individual and contextual factors. Trust stimulates successful leadership. It is the real relationship dimension in their work structure and this interaction are main part in relationship performance. This is the symbol for corporate sharing, sharing and managing the agreement. [24]. We are all naturally know what trust means, but there are actually two kinds of trust that are essential 
result in a good leadership. Affective trust, known as 'trust of the heart'. It is made up by empathy, closeness, and sincere consideration and concern. Affect-based trust is especially important as employees make personal investments in building trusting relationships, expressing concern, and caring for the well-being of others, which in turn are reciprocated [18] [25]. From [26] define affective trust is made up by empathy, proximity, and sincere consideration and concern. Hence, affective trust defined as sence of confident on their beliefs during conversation [23] . Thus, leaders with high affective trust result in less vision and less intellectual stimulation behaviour. This can be clarified by leaders with a high degree of affective trust who feel less like they need to earn people attention and concern. And yet frequent visioning is necessary to realign priorities, objectives and targets within a team in order to overcome the natural inclination to wander off course for these issues.

Previous research findings, the leader and employee relationship from the basis fo trust and sence of respect, hence leadership, cognitive and affect-based trust a significant correlation among them. In fact, the altruism has a positive effect on the relationship on the morale and efficiency of the employee and can provide a basis for granting affected trust [18]. The communication through affective trust can impact leadership performance by human touch and good relationships between the leader, colleagues or customers itself. It is also promoting the effectiveness of servant leadership in delivering their task. Research conduct by [27] affective trust intercept the relationship of benevolence and authoritarianism on employee innovation and knowledge delivery. Affective trust is not only lead to the effectiveness of servant leadership but also promotes innovation and germination of fresh ideas in any task. This can have resulted in a good servant leadership performance. In this context, the servant leadership style is considered to be ineffective or outperform without a transactional relationship (i.e. affective based trust) between leader and the follower. Since the theory of servant leadership evolved and its measurement scales, most of the study centred on behavioural contexts in which servant leadership is more or less likely impacted. Based on the findings in [18], we can better understand how servant leadership affects the behavioural outcomes of employees by concentrating on trust building and quality relationships.

\section{Conclusion and Recommendation}

In conclusion, this study highlights the significance and impact of ttrust and motivation in the medical and health industry. Trust is a concern for the motivation to comply with the regulation, increase revenue, and employees trust in the organization. A framework for further research in this study is proposed based on the identified issues regarding leadership, trust and motivation.

\section{Acknowledgements}

Acknowledgements. Special appreciation to Universiti Teknologi MARA, Cawangan Pulau Pinang for providing the budget for this research study. 


\section{References}

[1] P. Bayram and K. Zoubi, "The effect of servant leadership on employees' self-reported performance: Does public service motivation play a mediating explanatory role?," Manag. Sci. Lett., 2020, doi: 10.5267/j.msl.2020.1.002.

[2] B. P. Owens and D. R. Hekman, "Modeling how to grow: An inductive examination of humble leader behaviors, contingencies, and outcomes," Acad. Manag. J., 2012, doi: 10.5465/amj.2010.0441.

[3] D. V Day, The Oxford handbook of leadership and organizations. Oxford Library of Psychology, 2014.

[4] G. P. Allen, W. Mark Moore, L. R. Moser, K. K. Neill, U. Sambamoorthi, and H. S. Bell, "The role of servant leadership and transformational leadership in academic pharmacy," Am. J. Pharm. Educ., 2016, doi: 10.5688/ajpe807113.

[5] J. C. Maxwell, Christian reflections on the leadership challenge, vol. 143. John Wiley \& Sons, 2009.

[6] P. G. Northouse, Leadership: Theory and practice. Sage publications, 2018.

[7] J. A. Laub, "Assessing the servant organization; Development of the Organizational Leadership Assessment (OLA) model. Dissertation Abstracts International," Procedia - Soc. Behav. Sci., 1999, doi: 10.1525/sp.2007.54.1.23.

[8] L. C. Spears, "Servant leadership and Robert K. Greenleaf's legacy," in Servant leadership, Springer, 2010, pp. 11-24.

[9] R. F. Russell and A. Gregory Stone, "A review of servant leadership attributes: developing a practical model," Leadership \& Organization Development Journal. 2002, doi: $10.1108 / 01437730210424$.

[10] D. Carter and T. Baghurst, "The Influence of Servant Leadership on Restaurant Employee Engagement," J. Bus. Ethics, 2014, doi: 10.1007/s10551-013-1882-0.

[11] D. M. Mayer, M. Bardes, and R. F. Piccolo, "Do servant-leaders help satisfy follower needs? An organizational justice perspective," Eur. J. Work Organ. Psychol., 2008, doi: 10.1080/13594320701743558.

[12] J. D. Lanctot and J. A. Irving, "Character and Leadership : Situating Servant Leadership in a Proposed Virtues Framework," 2007.

[13] D. L. Parris and J. W. Peachey, "A Systematic Literature Review of Servant Leadership Theory in Organizational Contexts," J. Bus. Ethics, 2013, doi: 10.1007/s10551-012-1322-6.

[14] É. Lapointe and C. Vandenberghe, "Examination of the Relationships Between Servant Leadership, Organizational Commitment, and Voice and Antisocial Behaviors," J. Bus. Ethics, 2018, doi: 10.1007/s10551-015-3002-9.

[15] H. Liu, "Just the Servant: An Intersectional Critique of Servant Leadership," J. Bus. Ethics, 2019, doi: 10.1007/s10551-017-3633-0.

[16] A. Newman, G. Schwarz, B. Cooper, and S. Sendjaya, "How Servant Leadership Influences Organizational Citizenship Behavior: The Roles of LMX, Empowerment, and Proactive Personality," J. Bus. Ethics, 2017, doi: 10.1007/s10551-015-2827-6.

[17] S. J. Reinke, "Service before self: Towards a theory of servant-leadership," Glob. Virtue Ethics Rev., 2004, doi: http://dx.doi.org/10.1108/17506200710779521.

[18] S. Seto and J. C. Sarros, "Servant Leadership Influence on Trust and Quality Relationship in Organizational Settings.," Int. Leadersh. J., vol. 8, no. 3, 2016.

[19] F. Saleem, Y. Z. Zhang, C. Gopinath, and A. Adeel, "Impact of Servant Leadership on Performance: The Mediating Role of Affective and Cognitive Trust," SAGE Open, 2020, doi: $10.1177 / 2158244019900562$.

[20] S. Parayitam and R. S. Dooley, "The relationship between conflict and decision outcomes," Int. J. Confl. Manag., 2007.

[21] S. Hussain, M. Shujahat, M. I. Malik, S. Iqbal, and F. N. Mir, "Contradictory results on the mediating roles of two dimensions of trust between transformational leadership and employee outcomes," J. Organ. Eff., 2018, doi: 10.1108/JOEPP-11-2016-0063. 
[22] R. C. Liden, S. J. Wayne, J. D. Meuser, J. Hu, J. Wu, and C. Liao, "Servant leadership: Validation of a short form of the SL-28," Leadersh. Q., 2015, doi:

10.1016/j.leaqua.2014.12.002.

[23] R. Islam, N. Osman, M. F. Othman, and M. Abu Raihan, "Impact of global leadership behaviors on performance of multinational companies," Humanit. Soc. Sci. Rev., 2019, doi:

10.18510/hssr.2019.7397.

[24] K. T. Dirks and D. L. Ferrin, “Trust in leadership: Meta-analytic findings and implications for research and practice," J. Appl. Psychol., 2002, doi: 10.1037/0021-9010.87.4.611.

[25] R. Cropanzano and M. S. Mitchell, "Social exchange theory: An Interdisciplinary review," Journal of Management. 2005, doi: 10.1177/0149206305279602.

[26] Y. Tu, Y. Zhang, X. Lu, and S. Wang, "Differentiating two facets of trust in colleagues: How ethical leadership influences cross-team knowledge sharing," Leadersh. Organ. Dev. J., 2019, doi: 10.1108/LODJ-06-2019-0260.

[27] Q. Tian and J. I. Sanchez, "Does paternalistic leadership promote innovative behavior? The interaction between authoritarianism and benevolence," J. Appl. Soc. Psychol., 2017, doi: 10.1111/jasp.12431. 